\title{
Total Intravenous Anaesthesia (TIVA) in Veterinary Practice
}

\author{
Rukmani Dewangan ${ }^{1}$, S. K. Tiwari ${ }^{2}$ \\ ${ }^{1,2}$ Department of Veterinary Surgery and Radiology, College of Veterinay Science and A.H. Anjora Durg (C.G.), India
}

\begin{abstract}
Total intravenous anaesthesia (TIVA) is defined as a technique of general anaesthesia using a combination of agents given solely by the intravenous route and in the absence of inhalational agents. This article reviews the indications, advantages and disadvantages, principle, mode of administration, clinical techniques and drugs used for TIVA. Total intravenous anesthesia, or TIVA, can provide a valuable alternative to inhalation anaesthesia as one of the most important drawbacks of this technique, however, is that it pollutes the environment.
\end{abstract}

Keywords: intravenous, anaesthesia, analgesia, TIVA

\section{Introduction}

Total intravenous anaesthesia (TIVA) may be defined as a technique of general anaesthesia using a combination of agents given solely by intravenous route and in absensce of all inhalation agents including nitrous oxide. An ideal anaesthetic produces sleep, amnesia, analgesia and muscle relaxation. As all these characteristics cannot be provided by a sole agent, a combination of drugs is used. This technique is referred to as "balanced anaesthesia". For many years it has been accepted that the best anaesthetic protocols involved use of injectable drugs to induce anaesthesia, followed by intubation and maintenance of anaesthesia with volatile, inhaled anaesthetic drugs (combined anaesthesia/balanced anaesthesia). Earlier inhalation anaesthesia was considered as gold standard of anaesthesia maintenance, especially because of its rapid onset and recovery and the ease of controlling depth of anaesthesia. The inhalant anaesthetics have no analgesic properties and only prevent pain perception by rendering the animal unconscious. The volatile anaesthetics which are predominantly in use today are: halothane, isoflurane and sevoflurane and the use of these inhalants requires special anaesthetic delivery equipment which is complex, costly and bulky including a suitable breathing system and vaporizer.

Recently, there has been much interest in total intravenous anaesthesia (TIVA), where IV agents provide the main aspects of surgical anaesthesia: unconsciousness, muscle relaxation and analgesia. TIVA means use of intravenous agent exclusively to provide complete anaesthesia. This involves four components of general anaesthesia that is block of mental, reflex, sensory and motor functions. TIVA has found its place as preferred technique because of its advantages. Total intravenous anesthesia (TIVA) is now commonly used in veterinary institutions as an alternative to the use of inhalation anesthetics because it does not require specialized equipment or an oxygen delivery system. One of the main reasons that TIVA is being used in veterinary institutions is that the intravenous agents cause less cardiovascular and respiratory depression than the inhalation anesthetics. The recovery is early and complete even following prolonged use. It can be used to induce anaesthesia with a single bolus and then to maintain anaesthesia using constant rate of infusion. There are cases that will benefit from TIVA, such as animals with intracranial hypertension. The procedure determines the appropriate TIVA protocol. Diagnostic imaging and nonpainful procedures can be done by using a hypnotic (propofol) while painful surgical procedures will require a hypnotic, an opioid, and possibly ketamine. In very sick animals (e.g., septic patients), a combination of a benzodiazepine and an opioid for TIVA may be appropriate.

\section{Advantages of TIVA}

1) Reduces the pollution hazard in Operation Theater as environmental contamination is common with inhalation agents

2) Avoide repeating administration of toxic drugs

3) Quick induction and reversal alongwith superior recovery

4) Reduced postoperative nausea and vomiting

5) Easy to titrate drugs

6) Provide stable plane of anaesthesia and completely independent of patient "s airways and breathing system

7) No anaesthetic vaporizer is needed

8) Improved cerebral blood flow autoregulation for patients with brain diseases

9) Maintains hypoxic pulmonary vasoconstriction response

10)Not known to trigger malignant hyperthermia

\section{Disadvantages of TIVA}

1) Equipment needed, such syringe drivers or infusion pumps for accurate administration

2) Drugs will require metabolism for recovery from anaesthesia, which may be prolonged in animals with hepatic disease.

\section{Indications}

1) Surgical procedures that involved the upper airway when placement of an endotracheal tube will interfere with surgery.

2) Bronchoscopic evaluation in smaller patients is facilitated by the use of TIVA. A bronchoscope can be inserted into the endotracheal tube; however, this procedure cannot be performed in very small patients since the bronchoscope cannot be inserted into the small endotracheal tubes.

3) The use of IV agents as a form of general anaesthesia for patients with intracranial hypertension such as an 


\section{International Journal of Science and Research (IJSR) \\ ISSN (Online): 2319-7064 \\ Index Copernicus Value (2013): 6.14 | Impact Factor (2015): 6.391}

intracranial tumor is highly recommended, because inhalant agents increase blood flow to the brain while IV agents like propofol reduces the cerebral blood flow.

4) Other uses of CRI using propofol include patients with postoperative seizures after portosystemic shunt ligation, anaesthesia/sedation for patients that are mechanically ventilated in an intensive care setting, patients undergoing magnetic resonance imaging, radiation therapy and any general anaesthesia when an anaesthetic machine is not available.

\section{Principle of TIVA}

TIVA is based on the principle that a plasma drug concentration needed to produce anaesthesia has to be reached quickly and maintained over the period of time that anaesthesia is planned. A loading dose is determined based on the volume of distribution and the initial plasma drug concentration. This is determined by pharmacokinetic studies in animals. With hypnotic agents like propofol, the loading dose is calculated and given to effect. Following initial administration, the drug is both redistributed to tissues and eliminated. Therefore, to maintain the desired plasma drug concentration, a constant rate infusion (CRI) is initiated. The infusion rate is determined by the clearance of the drug and the plasma drug concentration in plasma (also based on pharmacokinetic studies). There will be individual variation as to the response of animals to the CRI of the drug. Lightening of the anaesthetic plane can be corrected by intravenous (IV) bolus of additional drug.

\section{Drugs Used for TIVA}

Ideal drug of TIVA should have analgesic properties and thus contribute to pre-emptive analgesia thereby reducing reflex responses to noxious stimuli alongwith more rapid onset and recovery profile. Therefore, drugs used for TIVA should possess most of the following properties: a) watersoluble to minimize toxicity associated with the solvent, b) stable in solution, c) no perivascular sloughing if extravasated, d) given in concentrated solution to avoid fluid overloading, e) not absorbed by plastics, f) does not promote bacterial growth, g) rapid onset of action, h) cleared rapidly from the body for a more rapid and predictable recovery, i) devoid of adverse side effects, j) potent and lipid-soluble, $k$ ) relatively cheap and l) chemically compatible with other drugs. Following drugs can be used individually or in combination are Hypnotics- Propofol, Ketamine, Etomidate, Barbiturate, Diazepam, Midazolam ; Analgesics- Fentanyl, Sufentanyl, Alfentanyl, Methodone, Morphine and Muscle relaxants. Drugs commonly used for TIVA in dogs and cats are shown in Table 1. Propofol, a hypnotic agent, is the most commonly used agent for TIVA. It has a higher elimination clearance and a shorter elimination half-life compared with other injectable agents. The clearance rate of propofol is faster than the liver blood flow. The recoveries from propofol are judged to be good. The other injectable agents available commercially have some undesirable features making them less preferred for TIVA. Thiopental, a commonly used IV induction agent, is not suitable for TIVA because of prolonged recovery associated with longer infusions. Ketamine, another commonly used injectable in practice can be added to the other agents for TIVA. By itself, some metabolites of ketamine are active and will accumulate, resulting in prolonged drug action. Etomidate, which maintains good cardiopulmonary function, has been tried as a maintenance agent; however, it has several detrimental effects. It suppresses the production of cortisol. The high concentration of propylene glycol in etomidate preparation causes hemolysis resulting in hemoglobinuria. Etomidate is more expensive compared with other injectable agents.

Table 1: Drugs Used for TIVA in Dogs and Cats

\begin{tabular}{|c|c|c|c|}
\hline Drugs & $\begin{array}{l}\text { Initial } \\
\text { IV } \\
\text { dose }\end{array}$ & $\begin{array}{l}\text { CRI dose } \\
\text { (IV) }\end{array}$ & Comments \\
\hline Diazepam & $\begin{array}{l}0.1- \\
0.25 \\
\mathrm{mg} / \mathrm{kg}\end{array}$ & $\begin{array}{l}0.2-0.5 \\
\mathrm{mg} / \mathrm{kg} / \mathrm{hr}\end{array}$ & $\begin{array}{l}\text { Given with an } \\
\text { opioid }\end{array}$ \\
\hline Midazolam & $\begin{array}{l}0.1- \\
0.20 \\
\mathrm{mg} / \mathrm{kg}\end{array}$ & $\begin{array}{l}0.2-0.5 \\
\mathrm{mg} / \mathrm{kg} / \mathrm{hr}\end{array}$ & $\begin{array}{l}\text { Given with an } \\
\text { opioid }\end{array}$ \\
\hline Fentanyl & $\begin{array}{l}5-10 \\
\mu \mathrm{g} / \mathrm{kg}\end{array}$ & $\begin{array}{l}0.2-2.0 \\
\mu \mathrm{g} / \mathrm{kg} / \mathrm{min}\end{array}$ & $\begin{array}{l}\text { For CRI, use lower } \\
\text { dose rate first }\end{array}$ \\
\hline Remifentanil & $\begin{array}{l}5-10 \\
\mu \mathrm{g} / \mathrm{kg}\end{array}$ & $\begin{array}{l}0.2-2.0 \\
\mu \mathrm{g} / \mathrm{kg} / \mathrm{min}\end{array}$ & $\begin{array}{l}\text { For CRI, use lower } \\
\text { dose rate first }\end{array}$ \\
\hline Sufentanil & $\begin{array}{l}2-5 \\
\mu g / k g\end{array}$ & $\begin{array}{l}0.1-0.2 \\
\mu g / \mathrm{kg} / \mathrm{min}\end{array}$ & --- \\
\hline Alfentanil & $5 \mu \mathrm{g} / \mathrm{kg}$ & $\begin{array}{l}1.0 \\
\mu \mathrm{g} / \mathrm{kg} / \mathrm{min}\end{array}$ & $\begin{array}{l}1 / 7-1 / 10^{\text {th }} \text { the } \\
\text { potency of fentanyl }\end{array}$ \\
\hline Propofol & $\begin{array}{l}1-4 \\
\mathrm{mg} / \mathrm{kg}\end{array}$ & $\begin{array}{l}0.2-0.5 \\
\mathrm{mg} / \mathrm{kg} / \mathrm{min}\end{array}$ & -- \\
\hline Etomidate & $\begin{array}{l}1-2 \\
\mathrm{mg} / \mathrm{kg}\end{array}$ & $\begin{array}{l}0.02-0.3 \\
\mathrm{mg} / \mathrm{kg} / \mathrm{min}\end{array}$ & $\begin{array}{l}\text { Not suitable for } \\
\text { prolonged infusion } \\
\text { because of adrenal } \\
\text { suppression and } \\
\text { hemolytic effect of } \\
\text { propylene glycol }\end{array}$ \\
\hline $\begin{array}{l}\text { Midazolam } \\
\text { Fentanyl }\end{array}$ & $\begin{array}{l}0.2 \\
\mathrm{mg} / \mathrm{kg} \\
\mathrm{IV} \\
10 \\
\mathrm{ug} / \mathrm{kg}\end{array}$ & $\begin{array}{l}8.0 \\
\mathrm{ug} / \mathrm{kg} / \mathrm{min} \\
0.8-2.0 \\
\mathrm{ug} / \mathrm{kg} / \mathrm{min}\end{array}$ & $\begin{array}{l}\text { To complete } \\
\text { induction, propofol } \\
\text { may be needed }\end{array}$ \\
\hline
\end{tabular}

\section{Mode of Administration}

TIVA always involves the delivery of a bolus dose or a fast loading infusion to achieve an adequate blood concentration of the anaesthetic drug. Maintenance of anaesthesia can be obtained by administering intermittent boluses, by continuous rate infusion or by target-controlled infusion.

\section{1) Intermittent Boluses}

Once anaesthesia is induced, it may be maintained using small intermittent boluses of a short-acting intravenous hypnotic induction agent such as propofol. This technique is very simple and only requires a syringe and cannula for intravenous access. The plasma drug concentrations tend to oscillate between peaks (potentially causing increased side effects such as apnoea or hypotension) and troughs (resulting in inadequate anaesthesia). The intermittent bolus administration of a drug may result in high peak plasma concentrations and excessive depth of anaesthesia and side effects, alternating with periods of inadequate anaesthesia and the possibility of awareness. 


\section{International Journal of Science and Research (IJSR) ISSN (Online): 2319-7064 \\ Index Copernicus Value (2013): 6.14 | Impact Factor (2015): 6.391}

\section{2) Constant rate infusion (CRI)}

The administration of anaesthetic agents using continuous infusion techniques eliminates the peaks and troughs in plasma drug concentration that occur with the use of intermittent boluses. The result is a better quality of anaesthesia, which is achieved using a lower total drug dose. When continuous infusion is used, the anaesthetics can be administered as a continuous rate infusion (CRI), either with or without manual adjustment (variable rate infusion or VRI), or by using a volumetric infusion pump or a syringe driver. The cheapest but least accurate way of providing continuous infusion anaesthesia is to use a bag containing the hypnotic agent(s) and a giving simply via an infusion set. The flow rate can be adjusted by varying the diameter of the infusion tubing using a ,regulatinge clamp (fig.1). The infusion rate can be calculated by knowing the volume of each drop (20 versus 60 drops per $\mathrm{ml}$ ) and counting the drip rate. An increase of sophistication is to incorporate a specific volume pump. Preferable is via a CRI syringe driver. Infusion pumps and syringe drivers can be used to achieve a more continuous, controlled, accurate and safer infusion. Large volume infusions are more accurately administered using an infusion pump (fig.2), while a syringe driver (fig.3) is more appropriate for smaller volumes administered at slower rates. They can be set to deliver a certain pre-calculated rate - if the anaesthesia is light it can deliver a bolus, or the rate can be changed as required according to the depth of anaesthesia. The calculated drug dosage for infusion intra-operatively with syringe drivers for dogs and cats are given in Table 2. Modern infusion devices are able to detect air in the system and line blockages.

Potential hazards associated with infusion pumps and syringe drivers include:

1) An excessively rapid rate of infusion (due to, for example, the administration set not being properly clamped);

2) Power failure (mains or battery);

3) Infusion of air, if a cannula becomes dislodged.

The position of a syringe driver is important. If it is positioned higher than the vascular access, siphoning may occur due to the weight of the liquid, causing more than the programmed level of drugs to be administered. The device should therefore be protected to prevent the syringe plunger from moving faster than its motor drive. Conversely, if the syringe driver is positioned lower than the vascular access, less agent than programmed is infused due to the back pressure from the venous bed and the weight of the liquid. To avoid these problems, infusion sets should incorporate a one-way valve. If the syringe driver is positioned vertically, the outlet should be placed downwards to prevent bubbles formed by gas coming out of the solution being infused into the patient.

Table 2: Drug Dosages For Infusion Intra-Operatively With Syringe Drivers For Dogs And Cats.

\begin{tabular}{|c|c|c|c|c|}
\hline Name & $\begin{array}{c}\text { Dose range } \\
\mathrm{mg} / \mathrm{kg} / \mathrm{hr}\end{array}$ & $\begin{array}{c}\text { Standard strength } \\
\text { preparation } \mathrm{mg} / \mathrm{ml}\end{array}$ & Dilution for infusion & Dose ml.kg/hr \\
\hline Propofol & $6-24$ & 10 & Undiluted & $0.6-2.4$ \\
\hline Alfaxalone & $4-8$ & 10 & Undiluted & $0.4-0.8$ \\
\hline Fentanyl & $0.005-0.015$ & 0.05 & Depends upon the size & $0.1-0.3$ \\
\cline { 3 - 5 } & & & $\begin{array}{c}\text { If }>15 \mathrm{~kg} \text { undiluted } \\
\text { fentanyl with } 10 \mathrm{ml} \text { saline }\end{array}$ & $0.2-0.6$ \\
\hline Morphine & $0.1-0.2$ & 10 & Dilute $1 \mathrm{mg} / \mathrm{ml}$ by adding $1 \mathrm{ml}$ to $9 \mathrm{ml}$ saline & $0.1-0.2$ \\
\hline Medetomidine & $0.001-0.002$ & 1 & $\begin{array}{c}\text { Dilute to } 0.01 \mathrm{mg} / \mathrm{ml} \text { by adding } 0.5 \mathrm{ml} \text { to } 49.5 \\
\text { ml saline }\end{array}$ & $0.1-0.2$ \\
\hline Dexmedetomidine & $0.0005-0.001$ & 0.5 or 0.1 & $\begin{array}{c}\text { Dilute to } 0.01 \mathrm{mg} / \mathrm{ml} \text { either by adding } 1 \mathrm{ml} \text { to } 49 \\
\text { ml saline for } 0.5 \mathrm{mg} / \mathrm{ml} \text { or by adding } 0.1 \mathrm{ml} \text { to } \\
9.9 \mathrm{ml} \text { saline for } 0.1 \mathrm{mg} / \mathrm{ml}\end{array}$ & $0.05-0.1$ \\
\hline Lidocaine (not cats) & $3-6$ & & Undiluted & $0.15-0.3$ \\
\hline Ketamine & $0.6-1.2$ & 20 & Dilute $2 \mathrm{mg} / \mathrm{ml}$ by adding $1 \mathrm{ml}$ to $49 \mathrm{ml}$ saline & $0.3-0.6$ \\
\hline
\end{tabular}

\section{3) Target Controlled Infusion.}

The more accurate way of achieving TIVA is the so-called target-controlled infusion (TCI). This technique involves computer-controlled administration of the anaesthetic by means of an infusion pump. The pharmacokinetic profile of the drug is programmed into the computer and the rate of infusion is determined on the basis of the rate of redistribution and elimination of the drug from the body. The result will approximate a stable plasma concentration of the drug, which can easily be adjusted in response to its clinical effects, more or less like the end tidal concentration of a volatile anaesthetic is adjusted. For TIVA with propofol (and later for remifentanil) in human anaesthesia, target controlled infusers, e.g., the Diprifusor ${ }^{\mathrm{TM}}$ have been developed. Physical factors of the patient are set, and then the infuser injects the propofol to a 'target' plasma concentration, based on pharmacokinetic calculations. The use of target controlled infusion systems has been described in cats using alfentanil and in horses using alfentanil and detomidine. The team from Glasgow developed a TCI system using propofol in dogs (fig. 4). Currently a company „Rugloop ${ }^{\text {TMee }}$ have developed a computer programme to drive infuser syringes, not just for propofol but also for other agents. Their software has been modified by incorporating the Glasgow pharmacokinetic model for dogs and appears to have been used successfully.

\section{Clinical Techniques}

To perform TIVA, the use of a syringe pump is highly desirable. The syringe pump can accurately deliver the anaesthetic dose over time and changes in delivery rate can be made more quickly. As an alternative, propofol can be infused using an IV administration set. For this technique, propofol is mixed with $5.0 \%$ dextrose in water. According to the manufacturer, propofol should only be diluted with $5.0 \%$ 


\section{International Journal of Science and Research (IJSR) \\ ISSN (Online): 2319-7064 \\ Index Copernicus Value (2013): 6.14 | Impact Factor (2015): 6.391}

dextrose in water and the final concentration of propofol should not be less than $2.0 \mathrm{mg} / \mathrm{ml}$. The diluted form has $95 \%$ potency after 2 hours of running infusion in plastic. This technique is feasible, but takes more time to prepare, allows more chances for contamination during preparation, and is less accurate. The drip rate may be difficult to control because changes in the height of the fluid column and occlusion of the IV line changes the drip rate.

a) Premedication is highly recommended before TIVA. The quality of induction is vastly improved with the use of premedicants. The choice of premedicants will depend on the physical condition of the animal. If the animal is in pain or if the surgical procedure is painful, an analgesic (opioid preferably) should be incorporated in the premedicants. A tranquilizer or sedative (benzodiazepines e..g. midazolam, diazepam, or alpha-2 agonist) should also be considered as part of premedication. The use of anticholinergic (atropine, glycopyrrolate) as preanesthetic is an option. stimulate the vagal tone and sinus bradycardia may occur following opioid administration. The administration an anticholinergic as premedicant routinely does not occur and is given when bradycardia occurs following and during opioid administration. Once sedation is achieved, anaesthesia is induced using propofol. A calculated dose of $4.0 \mathrm{mg} / \mathrm{kg}$ is drawn up. Depending upon the degree of sedation, a typical initial dose is one-half of the calculated dose and is given over 40-60 seconds. If the animal is still very light, the rest of propofol is given to effect. In procedures that will allow endotracheal intubation, an appropriately sized endotracheal tube is inserted and oxygen is supplied. Immediately after anaesthetic induction, infusion of propofol at 0.4-0.5 $\mathrm{mg} / \mathrm{kg} / \mathrm{min}$ is started. The infusion rate should be adjusted based on the depth of anaesthesia. It is important to remember that individual patients will vary in their anaesthetic requirements. If the plane of anaesthesia is getting too deep, characterized by lowering of blood pressure, decreased respiratory rate, and a central location eyeball without eye reflexes, the infusion rate can be reduced to as low as $0.2 \mathrm{mg} / \mathrm{kg} / \mathrm{min}$. In some instances, sudden application of surgical stimulus will lighten the plane of anaesthesia resulting in patient's movement. When this happens, a bolus dose of propofol should be given to rapidly to increase the blood concentration of propofol. The guideline is to give $10.0-20.0 \%$ of the induction dose actually given to the patient. This can be repeated based on the response of the animal. Following the bolus injection, the infusion rate may have to be increased by $0.1 \mathrm{mg} / \mathrm{kg} /$ min to maintain a higher plasma level, which the patient requires to maintain anaesthesia. Utmost attention should be made to monitor the depth of anaesthesia when the infusion rate is increased. Regular adjustments to the rate of infusion are expected for the first 2-3 hours following the loading dose.

b) A modification of above technique is to add an opioid infusion to the propofol infusion. Propofol does not possess analgesic property. The use of fentanyl or remifentanil for patients that undergoing painful procedures. The infusion ranges from $0.5-2.0 \mu \mathrm{g} / \mathrm{kg} / \mathrm{min}$. In this situation, ventilatory support is required due to respiratory depression brought about by the propofol and the opioid. For patients with hepatic and/or renal insufficiency, remifentanil is preferred over fentanyl. Remifentanil results in rapid equilibration between the blood and the brain such that a bolus dose before the CRI is not necessary. With fentanyl, a bolus dose should be given slowly to minimize sudden changes in arterial blood pressure and heart rate. The most common complication associated with a propofol CRI is respiratory depression. Hypoxemia can develop if the animal is inspiring room air. Administration of a higher concentration of oxygen via a facemask or endotracheal tube is advisable. Another possible complication associated with this technique is arterial hypotension. If the infusion rate is maintained at a higher level and the procedure being performed is not painful, blood pressure will decrease. If the procedure is mildly painful or not painful at all, light anaesthetic depth can be maintained characterized by the presence of weak palpebral reflex.

c) A further modification of TIVA is the inclusion of a neuromuscular blocking agent to the hypnotic and opioid. With this technique, all desired elements of the four components of general anaesthesia are provided. The neuromuscular blocking agent (atracurium, pancuronium, vecuronium) provides muscle relaxation. Sedative-hypnotic drugs (propofol) produce unconsciousness and amnesia. Opioids provide analgesia and decrease or stop reflex response to surgery. In this technique, the ventilation should always be controlled because the neuromuscular blocking agent paralyzes the diaphragm. This technique requires more equipment (mechanical ventilator and nerve stimulator) and expertise. Its application in clinical practice is also quite limited.

The induction and maintenance protocols for TIVA in the various species are shown in Table 3 . The infusion rates provided should be used as a guide and adapted depending on the patient's health status, age, premedication, and so on. Tracheal intubation should always be performed to secure the airways; this is particularly important in cattle and sheep to prevent the aspiration of ruminal contents. If possible, patients should be given a gas mixture containing at least $30 \%$ oxygen via an appropriate breathing system or demand valve. For each species, premedication (sedation and/or analgesia) is provided as described for inhalation anaesthesia. The very concentrated solutions of guaifenesin (7 per cent in cattle and sheep, and 15 per cent in horses) might cause haemolysis. Therefore, a total dose of 100 $\mathrm{mg} / \mathrm{kg}$ (this includes the induction dose for guaifenesin, if used) or one hour of infusion should not be exceeded, as an accumulation

of this agent can cause a prolonged and difficult recovery. It can be concluded that TIVA is an easy anaesthetic technique to provide excellent quality of anaesthesia which could be utilized in veterinary practices. It has its advantages and disadvantages, which should be considered while choosing an anaesthetic protocol for each case. 


\section{International Journal of Science and Research (IJSR) ISSN (Online): 2319-7064}

Index Copernicus Value (2013): 6.14 | Impact Factor (2015): 6.391

Table 3: Tiva Protocols For Various Species

\begin{tabular}{|c|c|c|}
\hline Animals & Induction & Maintenance \\
\hline Cattle & $\begin{array}{l}\text { Thiopental ( } 7 \text { to } 13 \mathrm{mg} / \mathrm{kg}) \mathrm{IV} \\
\text { Guaifenesin } 5 \% \text {, ketamine ( } 1 \text { to } 2 \mathrm{mg} / \mathrm{ml}) \\
\text { and xylazine }(0 \cdot 1 \mathrm{mg} / \mathrm{ml}) \text { mixture (triple } \\
\text { drip) at a rate of } 1 \text { to } 2 \mathrm{ml} / \mathrm{kg} \mathrm{IV}\end{array}$ & $\begin{array}{l}\text { Guaifenesin } 5 \% \text {, ketamine }(1 \text { to } 2 \mathrm{mg} / \mathrm{ml}) \text { and xylazine }(0 \cdot 1 \\
\text { mg/ml) mixture. } \\
\text { Average infusion rate } \\
\text { for adults- } 2 \mathrm{ml} / \mathrm{kg} / \text { hour } \\
\text { for calves- } 1.5 \mathrm{ml} / \mathrm{kg} / \text { hour }\end{array}$ \\
\hline Sheep & $\begin{array}{l}\text { Diazepam (5 mg/ml) and ketamine (100 } \\
\mathrm{mg} / \mathrm{ml}) \text { mixed together (at a ratio of } 1: 1) \text { at } \\
\text { a dose of } 0 \cdot 05 \text { to } 0 \cdot 1 \mathrm{ml} / \mathrm{kg} \mathrm{IV}\end{array}$ & $\begin{array}{c}\text { Propofol } 0 \cdot 3 \text { to } 0.5 \mathrm{mg} / \mathrm{kg} / \mathrm{minute} \\
\text { Guaifenesin } 5 \% \text {, ketamine ( } 1 \text { to } 2 \mathrm{mg} / \mathrm{ml}) \text { and xylazine }(0 \cdot 1 \\
\mathrm{mg} / \mathrm{ml} \text { ) mixture (triple drip). Average infusion rate of } 2 \mathrm{ml} / \mathrm{kg} / \text { hour }\end{array}$ \\
\hline \multirow[t]{2}{*}{ Horse } & $\begin{array}{l}\text { Ketamine ( } 2 \cdot 2 \mathrm{mg} / \mathrm{kg}) \text { with diazepam or } \\
\text { midazolam }(0 \cdot 04 \text { to } 0 \cdot 1 \mathrm{mg} / \mathrm{kg}) \mathrm{IV} \\
\text { Thiopental ( } 4 \text { to } 6 \mathrm{mg} / \mathrm{kg}) \text { alone or with } \\
\text { diazepam or midazolam }(0 \cdot 04 \\
\text { to } 0 \cdot 1 \mathrm{mg} / \mathrm{kg}) \mathrm{IV}\end{array}$ & $\begin{array}{l}500 \mathrm{mg} \text { xylazine and } 1 \mathrm{~g} \text { ketamine in } 500 \mathrm{ml} \text { of } 10 \% \text { guaifenesin. } \\
\text { Average infusion rate of } 1 \mathrm{ml} / \mathrm{kg} / \mathrm{hour} \\
25 \mathrm{mg} \text { romifidine and } 1 \mathrm{~g} \text { ketamine in } 500 \mathrm{ml} \text { of } 10 \% \text { guaifenesin. } \\
\text { Average infusion rate of } 0 \cdot 8 \mathrm{ml} / \mathrm{kg} / \mathrm{hour} \\
10 \mathrm{mg} \text { detomidine and } 1 \mathrm{~g} \text { ketamine in } 500 \mathrm{ml} \text { of } 10 \% \text { guaifenesin. } \\
\text { Average infusion rate of } 1 \mathrm{ml} / \mathrm{kg} / \mathrm{hour} \\
10 \mathrm{mg} \text { medetomidine (off-label use) and } 1 \mathrm{~g} \mathrm{ketamine} \mathrm{in} 500 \mathrm{ml} \text { of } \\
10 \% \text { guaifenesin. Average infusion rate of } 1 \mathrm{ml} / \mathrm{kg} / \text { hour }\end{array}$ \\
\hline & $\begin{array}{l}\text { Premedication with medetomidine (7 } \\
\qquad \mu \mathrm{g} / \mathrm{kg}) \mathrm{IV} \\
\text { Induction with propofol (12 mg/kg) IV }\end{array}$ & $\begin{array}{c}\text { Propofol } 10 \text { mg/kg/minute with medetomidine } 3 \cdot 5 \mu \mathrm{g} / \mathrm{kg} / \mathrm{hour} \text {. } \\
\text { Hypoxaemia can result, so oxygen } \\
\text { supplementation is advised }\end{array}$ \\
\hline Dog & $\begin{array}{c}\text { Ketamine (5 mg/kg) IV with diazepam or } \\
\text { midazolam ( } 0.5 \mathrm{mg} / \mathrm{kg}) \mathrm{IV} \\
\text { Propofol (4 to } 6 \mathrm{mg} / \mathrm{kg}) \mathrm{IV}\end{array}$ & $\begin{array}{c}\text { Ketamine } 2 \text { to } 4 \mathrm{mg} / \mathrm{kg} / \mathrm{hour} \text { with } \\
\text { medetomidine } 1 \mu \mathrm{g} / \mathrm{kg} / \mathrm{h} \text { our } \\
\text { Propofol } 0 \cdot 4 \mathrm{mg} / \mathrm{kg} / \mathrm{minute} \mathrm{IV} \pm \text { co-infusion } \\
\text { with fentanyl } 0 \cdot 2 \text { to } 0 \cdot 7 \mu \mathrm{g} / \mathrm{kg} / \mathrm{minute} \mathrm{IV} \\
\text { (painful procedure) or } \\
\text { morphine } 0 \cdot 1 \mathrm{mg} / \mathrm{kg} / \mathrm{hour} \pm \text { ketamine } 5 \text { to } 10 \mu \mathrm{g} / \mathrm{kg} / \mathrm{hour} \\
\text { IV(painful procedure) or medetomidine } 1 \mu \mathrm{g} / \mathrm{kg} / \mathrm{hour} \text { to provide } \\
\text { analgesia }\end{array}$ \\
\hline Cat & $\begin{array}{c}\text { Ketamine (5 mg/kg) IV with diazepam or } \\
\text { midazolam }(0.5 \mathrm{mg} / \mathrm{kg}) \mathrm{IV} \\
\text { Propofol (4 to } 6 \mathrm{mg} / \mathrm{kg}) \mathrm{IV}\end{array}$ & $\begin{array}{c}\text { Propofol } 0 \cdot 22 \mathrm{mg} / \mathrm{kg} / \mathrm{minute} \mathrm{IV} \pm \text { co-infusion } \\
\text { with medetomidine } 5 \mu \mathrm{g} / \mathrm{kg} / \mathrm{hour} \text { or } \\
\text { morphine } 0 \cdot 03 \text { to } 0 \cdot 05 \mathrm{mg} / \mathrm{kg} / \text { hour or } \\
\text { ketamine } 20 \text { to } 40 \mu \mathrm{g} / \mathrm{kg} / \mathrm{minute} \text { to provide } \\
\text { analgesia }\end{array}$ \\
\hline
\end{tabular}

\section{References}

[1] Beths, T. (2007). Total intravenous techniques for anaesthesia. Practice. 29: 410-413

[2] Beths, T., Glen, J.B., Reid, J., Monteiro, A.M. and Nolan, A.M. (2001). Evaluation and optimisation of a target-controlled infusion system for administering propofol to dogs as part of a total intravenous anaesthetic technique during dental surgery. Veterinary Record 148: 198-203

[3] Daunt, D.A., Dunlop, C.I. Chapman, P.L., Shafer, S.L., Ruskoaho, H., Vakkuri, O., Hodgson, D.S., Tyler, L.M. and Maze, M. (1993). Cardiopulmonary and behavioral responses to computer-driven infusion of detomidine in standing horses. American Journal of Veterinary Research 54: 2075-2082

[4] Ilkiw, J.E., Pascoe, P.J. and Fisher, L.D. (1997). Effect of alfentanil on the minimum alveolar concentration of isoflurane in cats. American Journal of Veterinary Research $58: 1274-1279$

[5] Pascoe, P.J., Steffey, E.P., Black, W.D., Claxton, J.M., Jacobs, J.R. and Woliner, M.J. (1993). Evaluation of the effect of alfentanil on the minimum alveolar concentration of halothane in horses. American Journal of Veterinary Research 54, 1327-1332

[6] Robson, K (2014). Benefits of total intravenous anaesthesia in dogs and cats. Vet Times. pp.1-15 


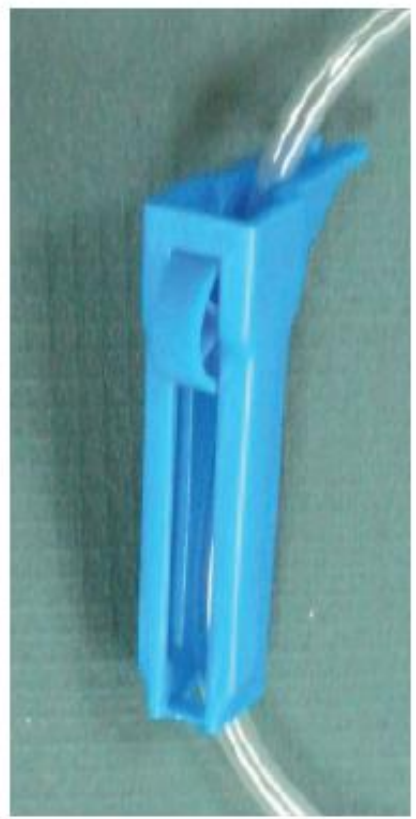

Figure 1: Regulating clamp attached to a giving set to regulate the amount of anaesthetic delivered

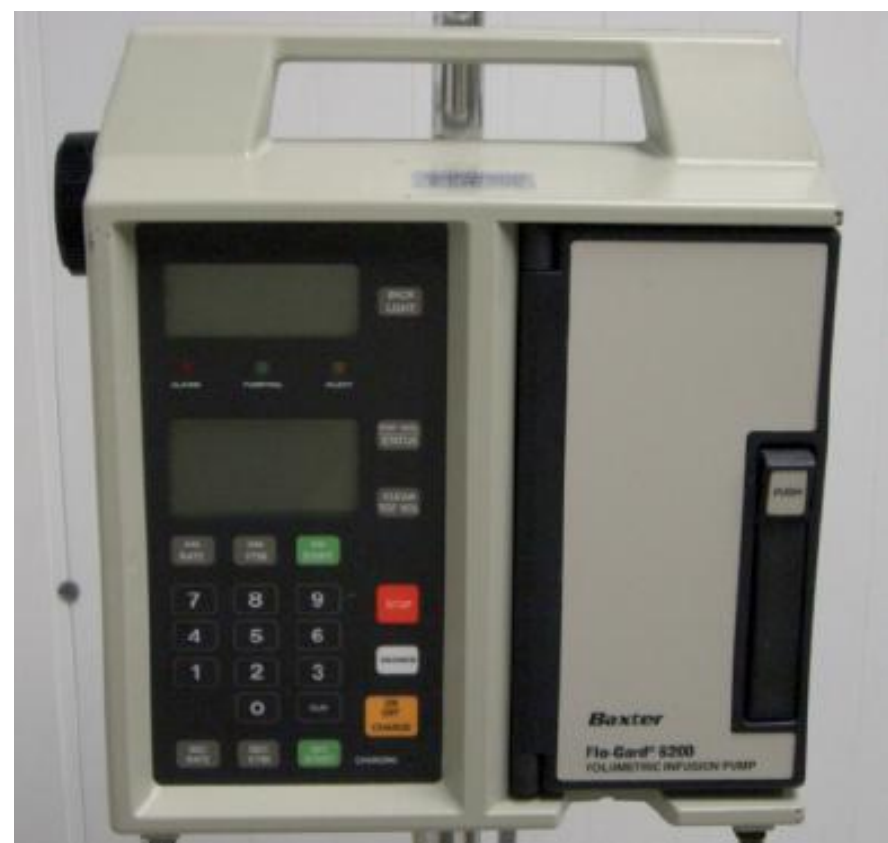

Figure 2: Volumetric Infusion pumps can be used to administer large volume infusions more accurately 


\section{International Journal of Science and Research (IJSR) \\ ISSN (Online): 2319-7064}

Index Copernicus Value (2013): 6.14 | Impact Factor (2015): 6.391

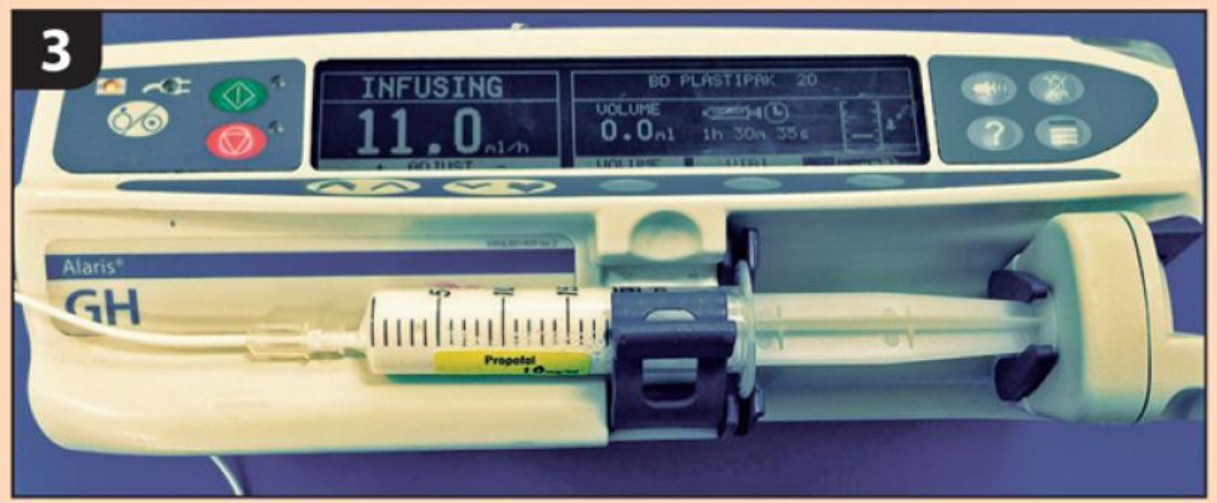

Figure 3: Syringe driver

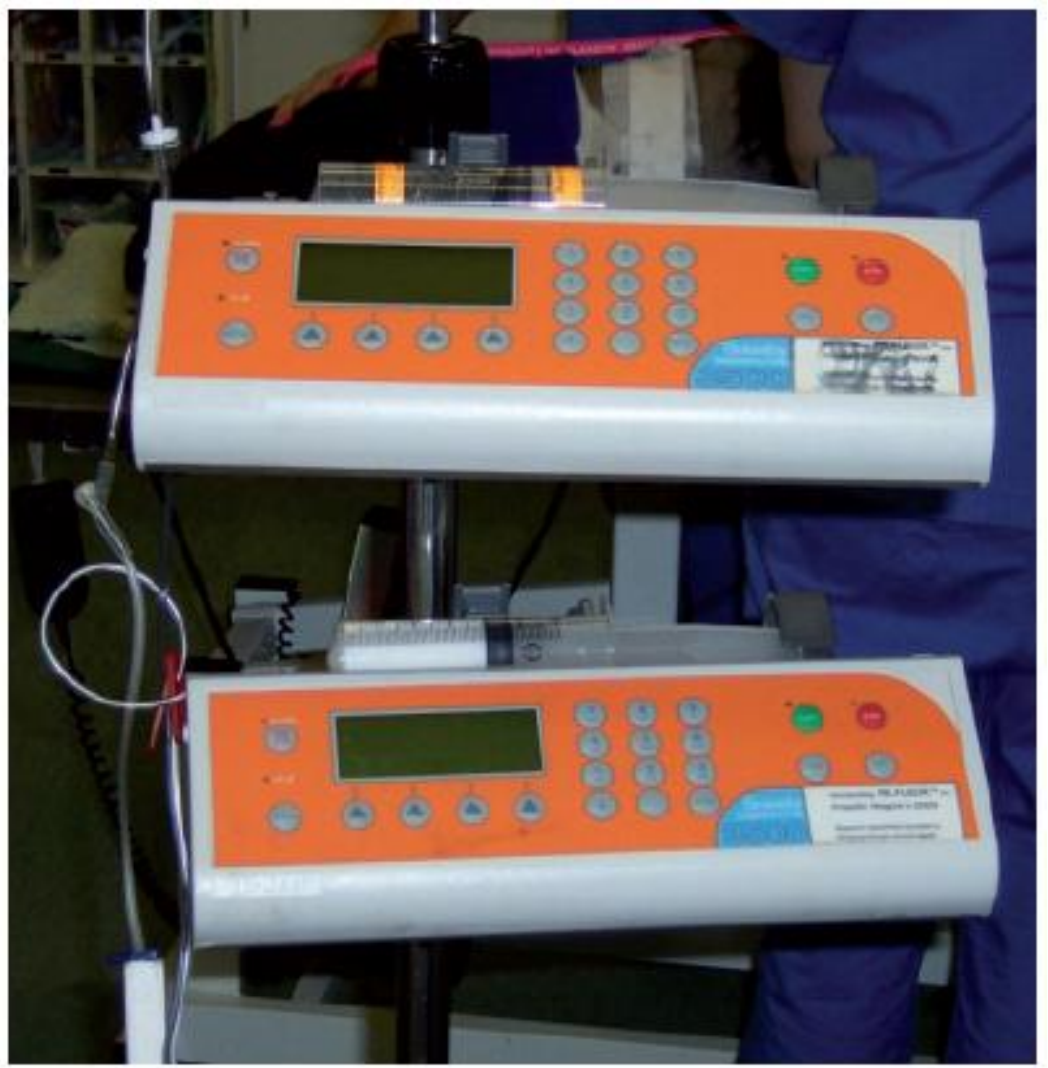

Figure 4: Two syringe drivers set in parallel during anaesthesia of dog. One infuses an analgesic (eg remifentanil) while the other is a target-controlled infusion system to provide anaesthesia using propofol 